\title{
The Habitus of Kyiv in the Epic Works by the Writers of the Literary Group "Lanka"-MARS
}

\author{
Olha Kryzhanovska ${ }^{1,{ }^{*}}$ Kateryna Protopopova ${ }^{2}$ Li Yalin $^{3}$
}

\author{
${ }^{1}$ Luhansk Taras Shevchenko National University, Ukraine \\ ${ }^{2}$ Kryvyi Rih State Pedagogical University, Ukraine \\ ${ }^{3}$ Lanzhou University of Technology, China \\ ${ }^{*}$ Corresponding author.Email: overnik16@gmail.com
}

\begin{abstract}
The research paper highlights the binary opposition of the masculine and the feminine in the urban habitus of Kyiv. The methodology of the research of the masculine and the feminine aspects of the urban habitus makes it possible to understand the connection of spatial dominants of the topos with all components of artistic texts. The masculine topos of Kyiv is embodied through the spatial vertical and incarnates the success of the characters, their sociopolitical life. The feminine habitus of Kyiv is embodied through the spatial horizontal and incarnates the "low" life of the characters, poverty, anti-urban leitmotifs. The research paper reveals the habitus of Kyiv in the epic works of the writers of Ukrainian literary group "Lanka"-MARS. The spatial characteristics of Kyiv and all components of poetics of works by Borys Teneta, Maria Galych, Hryhorii Kosynka, Borys AntonenkoDavydovych testify to the embodiment of the feminine urban habitus. Valerian Pidmohylny's novel "Misto" demonstrates the binary opposition of the masculine and the feminine in topos of Kyiv and represents the path of the character's ascent from the low (the feminine) to the high (the masculine) urban habitus of Kyiv.
\end{abstract}

Keywords: habitus of the city, Kyiv, “Lanka”-MARS, leitmotif, novel, short story, story, urbanism.

\section{INTRODUCTION}

The 1920s were marked by a real spiritual ascension in Ukrainian culture, in particular in literature, which was combined with a difficult everyday life, destruction, red terror, and the germs of authoritarianism. Difficult circumstances of everyday life have led to the fact that a large number of people from the countryside and small towns go to tremendous cities to conquer the megalopolis. This phenomenon has been the subject of consideration in the works of many authors. Ukrainian authors of the 1920s-1930s in their urbanistic works create the urban topos of Kyiv, Kharkiv, Lviv, represent the opposition of the city and village, which actualizes the motives of loneliness, the difficulty of assimilation to life in the city, hopelessness, contempt for eternal moral principles for the sake of a career, spiritlessness. This problem has become the subject of research by scientists who consider various aspects of the author's perception of the city $[1 ; 2 ; 3 ; 4]$.

The beginning of the 1920s in Ukraine was marked by the emergence of many literary associations that sought to renew artistic and cultural traditions on various artistic and aesthetic grounds. Most of the existing literary organizations at that time did not become a landmark phenomenon of the literary process and left almost no traces of their existence. The modern researchers consider that the writers of the literary group "Lanka"-MARS have left some of the best artistic achievements of that time $[5 ; 6 ; 7]$. The works of the writers were distinguished by their focus on the world literary process and the desire to preserve national characteristics. That is why the research of the peculiarities of the reception of Kyiv in the artistic work of the writers of the literary group "Lanka"MARS allows to see aspects that were characteristic not only for national literature but also for the whole world literature. The world political and economic processes of the 20th century became objective reasons for the intensification of the appeal to the problems of urbanism. The theme of the city dominated in the works of art of the world art, including the works by Valerian Pidmohylny, Borys Teneta, Maria Galych, Hryhorii Kosynka, Borys Antonenko-Davydovych. 
The modern researchers appeal to the study of such scientific categories as "the urban literature" and "the urban text", they analyze various aspects and modifications of these categories. Dmytro Boklakh researches the different interpretations and models of the topos of St. Petersburg in the works by Taras Shevchenko [8; 9]. Ievgeniia Voloshchuk explores Ukrainian topography in the poem "Flight Into Kyiv" by Hans-Ulrich Treichel and also represents German topos of Ukraine as a lost homeland [10]. Ostap Kin analyzes the features of topos of Lviv in works of fiction [11]. Ruslana Maryniak interprets the embodiment of the urban and the rustic artistic space in modern Ukrainian literature [12]. Nadiya Mikhno presents the city as an emotional space in terms of sociological analysis [13]. Oksana Oliinyk researches the connection between the city and the person's identity [14].The city as a cultural text is interpreted by Maryna Otrishko [15].The peculiarities of the artistic opposition of the heavenly and earthly city in the Hryhoriy Skovoroda's works are investigated by Olha Petrenko-Tseunova [16]. Denys Chyck researches the city and everyday life in the "physiological essays" by Volodymyr Dahl and Charles Dickens from a comparative-historical point of view [17]. The artistic image of Lviv in Ivan Franko's epic works became the subject of research by Alla Shvets [18].

The researcher Tatiana Khofman, in the framework of the study of literary ethnography of Ukraine, proves the advantages of studying the urban habitus over the urban text [19]. The urban habitus allows to see the conditionality of the plot, the nature of the characters, the problems and systems of motives of the work by the spatial conditions of the urban life. Tatiana Khofman highlights to the masculine and feminine structures of the urban habitus.

The goal of the research is to identify the components of the masculine and the feminine urban habitus of Kyiv by the writers of the literary group "Lanka"-MARS - Valerian Pidmohylny, Borys Teneta, Maria Galych, Hryhorii Kosynka, Borys Antonenko-Davydovych.

This will allow to see the commonality and originality of the artistic reception of Kyiv in the works of the writers who belonged to the same literary association.

\section{METHODS}

There were selected the most representative works of the writers of the literary group "Lanka"-MARS in the research paper to study the feminine and the masculine topos of Kyiv in literary texts of the epic literary genus - "Misto" by Valerian Pidmohylny, "Harmoniia i svynushnyk", "Misto", "Holod" by Borys Teneta, "Do birzhi", "Po dorozi" by Maria Galych, "Pid bramoiu soboru" by Hryhorii Kosynka, "Tuk-tuk", "Obraza", "Shchastia", "Shuraburia", "Semen Ivanovych Palokha" by Borys AntonenkoDavydovych. This textual representation allows to see the features of the artistic embodiment of the urban text by diverse writers who were part of the same literary organization and, apparently, transmitted general aesthetic principles.

There was used an integrated approach to achieve the goals of the article. The use of various research methods made it possible to objectively examine the feminine and the masculine aspects of urban texts. The comparative-typological method made it possible to determine the general and original in the representation of Kyiv by different authors, including at the thematic level, which helps to understand the originality of the writer's receptions and transformations of Kyiv text. Elements of the methodology of hermeneutics and semiotics were used to interpret specific works of art, to understand images and motives in the chronotope of epic texts. The main methodology of our research paper is based on the idea of Tatiana Khofman ("Literary Ethnographies of Ukraine: Prose after 1991") that it is productive to study urban topos as a spatial habitus that synthesizes artistic, cultural and everyday practices, works and styles, the city is viewed as a landmark structure between empirical and literary approaches. Tatiana Khofman puts forward the thesis about the possibility of considering Kiev as a binary opposition of the masculine and the feminine, upper and lower. The upper (the masculine) topos of Kyiv, which is presented as the source of East Slavic Orthodoxy, as the basis of Kievan Rus, as the personification of success, political and social life, is opposed by the base (the feminine) topos, which represents it as a "The Whore of Babylon", as a city with markers famine, poverty, hard life in the capital of a person who came from a village or province to conquer it; markers of romanticism, cosmopolitanism, carnivalism, private life of a person, inner experiences [19].

Studying the binary opposition of the masculine and the feminine, Tatiana Khofman takes into account the spatial characteristics of finding the characters or the action of the work that represent this opposition. The topographic vertical (city on slopes, mountains, location on a hill) testifies to the masculinity of the topos. The topographic horizontal (the image of the urban space near the river, on flat surfaces) shows the femininity of Kyiv. 
Therefore, our research paper is based on the model according to which the masculine Kyiv is represented through the spatial vertical (the location of the heroes' apartment on Kyiv hills, in the houses on the floors above the first or second) and reveals historical, political, social themes, embodies the success of the characters, their political life. The feminine Kyiv habitus is represented by the spatial horizontal (the location of the heroes' apartment on the river bank, on the plains, on the ground floor or in private houses) and it reproduces the hard every day life of the characters who came to conquer the capital, their poverty, famine, the disharmony of existence in the metropolis.

In the article of the masculine and the feminine topos of Kyiv in the epic works of the writers of the literary group "Lanka"-MARS, we rely on the outline concept of Tatiana Khofman. This concept will allow us to see the peculiarities of the presentation of topos of Kyiv, reveal the content of each element of the binary opposition in the spatial habitus of Kyiv.

\section{RESULTS AND DISCUSSIONS}

In the epic works of the writers of Ukrainian literary group "Lanka"-MARS the urban habitus of Kyiv consists of the characteristics of cultural and historical features of the city, the artistic worldview and the people who embody the main potential of the city. The novel "Misto" by Valerian Pidmohylny is based on the story of the provincial Stepan Radchenko, who came to study in Kyiv. During the novel there is not only a change in Stepan's attitude to the city, but a change in the character himself. Stepan Radchenko's internal changes lead to reconciliation with Kyiv and urban culture. The character, having adapted to life and assimilated in an unfamiliar environment, comes to the loss of connection with his small homeland, to the destruction of that part of his personality which embodied natural morality. The naive young man becomes a literary functionary, abandons his past, rural life, he easily transgresses the ethical laws, betrays friends and loved ones at the end of the work. The novel represents the path that yesterday's peasant must take in order to stay in the city, the ethical test of the character.

Valerian Pidmohylny's novel represents the idea of Stepan Radchenko's ascent from an unknown person to a recognized, successful writer. The character, having just arrived in Kyiv, lives in Nyzhnii Val, firstly in a barn, and then in the kitchen, for lunch he keeps the house with livestock, goes to classes at the university ("The barn is where he should live! Like a creature, like real livestock!” [20]). City life frightens the character, causes discomfort and protest, the desire to return. For the first time in a crowd of people, Stepan feels lonely and defenseless, negatively perceives the surrounding reality. He was pushed by "girls in thin blouses", women "in hats and a haze", men in jackets, young men "without hats, in shirts with sleeves rolled up to the elbows"; military "in heavy, stuffy uniforms" [20]. The Dnieper is the only consolation for the character. He feels real, finds peace and balance on the banks of the river. Here in Nyzhnii Val, the wife of the owner of the house teaches him love, he learns to understand female nature, female sexuality.

Obtaining a position in the lecture bureau for Urbanization cases leads the character to disappointment in Nyzhnii Val, he changes his apartment, moves to another place near his university. This represents the second stage of familiarization of Kyiv by Stepan Radchenko. Here the character initially lives simply, without luxury, according to a certain strict schedule, goes swimming on the Dnieper, is engaged in self-education, does physical exercises, tries to write works. His first literary success and royalties give Stepan self-confidence. Radchenko meets Zoska who is from Kyiv and she fell in love with him.

The release of the first collection of short stories of the character, the new position of the editor of a famous literary magazine contribute to the realization of the need to change the apartment and personal life. Stepan breaks off relations with Zoska, who commited suicide because of this. The character meets the famous actress Rita and decides to be with her. At the end of novel, the famous and successful Stepan bought an apartment in Lypky Pecherskyi raion, on the sixth floor of a seven-story building. It was visible "below the boundless landscape of the city and the distant horizon beyond the river" [20] from the window of the character 's new apartment. So, in the context of Tetiana Khofman's ideas, the character's transition from the feminine Kyiv with the a private person's life to the masculine city represented by the Pechersk hills, the apartment with landscape of the city, demonstrates the character's success, his transformation into a public figure. The evolution of the character's career, his assimilation in the city, the transition from the feminine to the masculine Kyiv are shown in Figure 1.

The image of Kyiv in the novel is presented by a detailed description of the streets, those traditional historical and memorable places, which determine the originality and peculiarity of the ancient city. The novel represents the cultural monuments of Kyiv and there is no industrial landscape. The writer makes 
Figure 1. The evolution of Stepan Radchenko's career

\begin{tabular}{|c|c|c|c|c|}
\hline $\begin{array}{c}\text { The spatial } \\
\text { characteristics of } \\
\text { Stepan } \\
\text { Rudchenko's life } \\
\text { in Kyiv }\end{array}$ & & \multirow{4}{*}{$\begin{array}{c}\text { Working in the lecture } \\
\text { bureau for } \\
\text { Urbanizalion cases, } \\
\text { publishing the first } \\
\text { collection of short } \\
\text { stories, love for loska }\end{array}$} & \multirow{4}{*}{$\begin{array}{l}\text { The position of the } \\
\text { editor of a famous } \\
\text { literary magazine, the } \\
\text { success of the first } \\
\text { collection of short } \\
\text { stories, the beginning } \\
\text { of writing a novel, } \\
\text { love for the famous } \\
\text { aciress Rila }\end{array}$} & \\
\hline $\begin{array}{l}\text { An own apartment } \\
\text { on the sixth floor } \\
\text { in Iypky } \\
\text { Pecherskyi raion }\end{array}$ & & & & \\
\hline $\begin{array}{l}\text { A room near the } \\
\text { university }\end{array}$ & 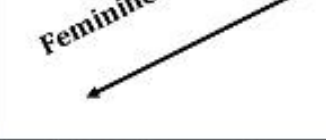 & & & \\
\hline \multirow[t]{2}{*}{ Nyzhnii Val } & $\begin{array}{l}\text { Living in poverty, } \\
\text { renting a room, getting } \\
\text { food as payment for } \\
\text { caring for livestock, } \\
\text { studying at the } \\
\text { university, being the } \\
\text { lover of the room } \\
\text { owner's wife }\end{array}$ & & & \\
\hline & The I stage & The II stage & The III stage & $\begin{array}{c}\text { Stepan } \\
\text { Radchenko's } \\
\text { career }\end{array}$ \\
\hline
\end{tabular}

mention of streets and districts, famous historical places: Andriivska tserkva, Askoldova mohyla, Volodymyrskyi sobor, Zoloti vorota, KyievoPecherska lavra, Sofiiskyi sobor, Tsarskyi sad, Istorychnyi muzei, Derzhavnyi akademichnyi teatr opery ta baletu URSR, Bessarabka, Demiivka, Lypky, Lukianivka, Pechersk, Stare misto, Arsenalna, Piatakova, Nyzhnii Val, Velyka Zhytomyrska, Velyka Pidvalna, Zhylianska, Sadova, Tarasivska, Mala Pidvalna, Khreshchatyk and so on.

There is no name of the city where the action takes place in the story "Harmoniia i svynushnyk" by Borys Teneta, but we can assume that it is about Kyiv, as evidenced by the details, including such lines, where the heroine looks at the city from above: "As you see from above, it lay flat with a ribbon of fire, with a necklace of fire over the Dnieper. The stars fell fate to earth from the sky" [21]. The main character of Borys Teneta's story "Harmoniia i svynushnyk" Kateryna, like other characters in the work, came to the city from the village in search of a better fate, this is where she tries to find harmony in life. At first, the city attracts her with its novelty, the girl compares it to life in the village, and dreams that everything in the city "is completely different, new and the people there are real people. In fact, in a big city, it should be new, not like here, where the deacon still reigns, and the men are drinking in the old way" [21]. But later Kateryna feels fear and frustration, the city seems more and more alien to her. More and more often the girl asks herself if it was a mistake to come to the city and betray the family tradition of living in the village. Gradually the character loses illusions about life in the city and loses the hope of being able to get rid of loneliness. Kateryna writes the story "Harmoniia i svynushnyk", where she tries to resolve the internal contradictions between the dream of turning the city into a happy, harmonious space and understanding the impossibility of realizing her dream.

Loneliness absorbs the character, she feels fear of the future. Realizing her own inability to bring order to the environment, Kateryna feels an all-consuming loneliness and alienation in the city, even in her relationship with Mykhailo, whom she loved. The guy who really loves the character and takes care about her, knowing about the girl's pregnancy, is indifferent to her desire to have an abortion. This reaction finally destroys Kateryna's inner world and leads her to a tragic final. This story is typologically close to Yevhen Pluzhnyk's novel "Neduha". The author recreates the story of experiences from unmutual love of Ivan Semenovych Orlovets to opera singer Iryna Eduardivna Zavadska, who chooses another man - an engineer Skvyrskyi. 
So, the chronotope of the work, all the psychological markers of the dispositions and natures of Borys Teneta's characters, the through motifs and images of the work represent the feminine topos of Kyiv. This is evidenced by the champaign horizontal and the Dnieper, near which the character lives on the outskirts of the city. According to Tetiana Khofman, feminine embodies disharmony, problems of private life, which is consistent with the issues and artistic space of the story by Borys Teneta. The feminine spatial habitus of "Kyiv text" of the work subordinates its problems and ideas, testifies to the fact that the character was doomed to a disharmonious existence between her own inner world and the surrounding life.

The femininity of "Kyiv text", which represents not only loneliness in a big city, the inability to find harmony between the external environment and the inner world, but also difficult living conditions, helplessness, is presented in other Borys Teneta's stories such as "Misto" and "Holod". In these works, the writer represents an anti-urban leitmotif.

The main character of the story "Misto" Mykhailo (this character is also depicted in the story "Harmoniia i svynushnyk"), feels both love and hate for the city that took his sister's life. The character understands that the city "sucks out blood, pulls veins" [22], but here he will stay, because there is a "sprouts of the future" [22]. In Borys Teneta's story "Holod" ("Bezrobitnyi") Petro, who dreams of becoming a writer, suffers from an all-consuming feeling of famine. The author focuses on the reproduction of the character's feelings, his hallucinatory perception of the world. The character dreams of food, as if in a movie he sees different dishes in front of him, talks to his own stomach, which subordinates the existence of the character: "The stomach, like a ferocious beast, howled and bit. A sour layer came under his throat and his head was spinning. I climbed in all corners and looked for pieces and bites" [23]. The feminine city which is represented by famine, poverty and helplessness in this text by Borys Teneta, takes away from Petro any freedom, leaves self-respect, dignity, and at the end - life.

The feminine Kyiv in Mariia Halych's work "Do birzhi" the author compares with "the golden crown on the gray Dnieper" [24]. The main character Natalia Voron lives near the Dnieper, which also testifies to the spatial affiliation to the feminine habitus of Kyiv. The character mistakenly lost the opportunity to study, found herself on the stock exchange among those people wishing to find work to survive in the city. The stock exchange is an environment that symbolizes the miserable situation of those people who get there, it is evidence that people are in a hopeless financial situation, almost at the bottom. Nastia from Mariia Halych's story "Po dorozi" came from the village to Kiev, because she believes that "you will not live only on the land" [24], so you need to "go to the people, look for income" [24]. The girl feels the cruelty of city life, due to selling cigarettes, she can afford only bread.

The feminine Kyiv is also represented in Hryhorii Kosynka's impressionistic short story-sketch "Pid bramoiu soboru", which reflects an episode from the life of "lower classes" - beggars [25]. The writer does not name the city in which the action takes place, but here it is obvious that it is Kyiv, in the text of the short story one of the ancient Kyiv cathedrals - Sofiivskyi. "Kyiv text" is created through the images of its townsfolk in this case beggars, and this Hryhorii Kosynka's short story typologically approaches to the works of other the writers of the literary group "Lanka"-MARS (Borys Teneta, Maria Galych, Borys Antonenko-Davydovych), in whose works Kyiv spatial habitus is also complemented by pictures of the miserable life of the townsfolk. In the short story the old beggar quarrels with others, snatches alms from their hands. The landscape is the contrast in the short story-sketch, nature opposes the pettiness and greed of the beggars. The image of the sun softens the heavy impression of a quarrel near the cathedral, it is not by accident that Hryhorii Kosynka begins and ends the work with it description.

Borys Antonenko-Davydovych's stories "Tuktuk", "Obraza", "Shchastia", "Shuraburia", "Semen Ivanovych Palokha" demonstrate the opposition of the feminine and the masculine in "Kyiv text" [26]. The author reproduces the perception of Kyiv by various characters who see not only its historical, Christian position, but also the crowded dirty streets, shops, pubs and so on. The writer appeals the themes of other "lanchany-marsivtsi": the opposition of the city and the village, the assimilation to life in Kyiv, the confusion in front of the crowd, the loneliness.

The prevalence of the feminine in the urban space of Kyiv testifies to the writers' representation of the "low" life of the capital, which is manifested through the topographic horizontal, neglected the urban landscape, helplessness and loneliness of the person in a tremendous environment, disharmony between external and internal world, the feelings of hostility.

Consequently, the spatial vertical, the images of historical and cultural monuments, the assimilation to life in the capital, career success, the psychological confidence and mutual love are the markers of the masculine Kyiv. All these markers are presented in a 
single work of the writers of the literary group "Lanka"-MARS in Valerian Pidmohylny's novel "Misto". The spatial horizontal, the abandoned cityscape, the anti-urban leitmotif, poverty, famine, the psychological insecurity, despair, loneliness and the death of the character are the markers of feminine Kyiv. All these characteristics, except of the death of the character, we have seen in "Misto" by Borys Teneta, "Do birzhi", "Po dorozi" by Mariia Halych, "Tuk-tuk", "Obraza", "Shchastia", "Semen Ivanovych Palokha" by Borys Antonenko-Davidovich, "Pid bramoiu soboru" by Hryhorii Kosynka. There are all the markers of feminine Kyiv, including the death of the character in "Harmoniia i svynushnyk" and "Holod" by Borys Teneta. The generalized markers of the masculine and the feminine Kyiv habitus in the texts of the writers of "Lanka"-MARS are given in Table 1.

\section{CONCLUSION}

In our research paper of the urban habitus of Kyiv, we relied on the model of the binary opposition of the masculine and the feminine, which was proposed by

Table 1. The markers of the urban habitus in the works of the writers of "Lanka"-MARS

\begin{tabular}{|c|c|c|c|c|c|c|c|c|c|c|c|c|c|}
\hline \multirow[b]{2}{*}{$\begin{array}{r}\text { Works of fiction } \\
\text { The markers } \\
\text { of the urban } \\
\text { habitus }\end{array}$} & \multicolumn{6}{|c|}{ The masculine Kyiv } & \multicolumn{7}{|c|}{ The feminine Kyiv } \\
\hline & 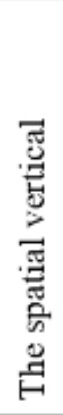 & 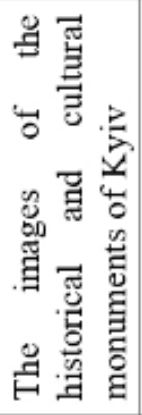 & 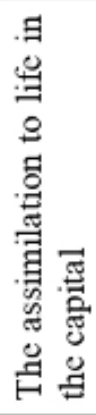 & 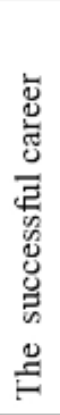 & 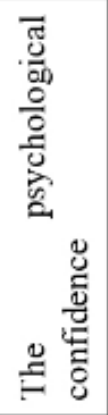 & 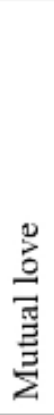 & 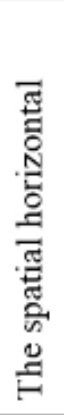 & 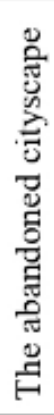 & 戛 & 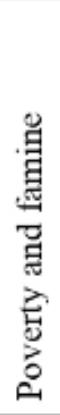 & 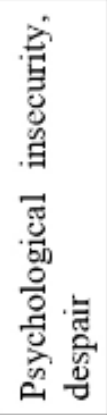 & 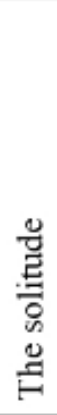 & 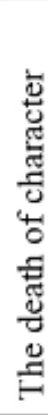 \\
\hline $\begin{array}{c}\text { "Misto" } \\
\text { by Valerian Pidmohylny }\end{array}$ & + & + & + & + & + & + & + & + & + & + & + & + & \\
\hline $\begin{array}{l}\text { "Harmoniia i } \\
\text { svynushnyk" } \\
\text { by Borys Teneta }\end{array}$ & & & & & & & + & + & + & + & + & + & + \\
\hline $\begin{array}{c}\text { "Misto" } \\
\text { by Borys Teneta }\end{array}$ & & & & & & & + & + & + & & + & + & \\
\hline $\begin{array}{c}\text { "Holod" } \\
\text { by Borys Teneta }\end{array}$ & & & & & & & + & + & + & + & + & + & + \\
\hline $\begin{array}{c}\text { "Do birzhi" } \\
\text { by Maria Galych }\end{array}$ & & & & & & & + & + & + & + & + & + & \\
\hline $\begin{array}{c}\text { "Po dorozi" } \\
\text { by Maria Galych }\end{array}$ & & & & & & & + & + & + & + & + & + & \\
\hline $\begin{array}{l}\text { "Pid bramoiu soboru" } \\
\text { by Hryhorii Kosynka }\end{array}$ & & & & & & & + & + & + & + & + & + & \\
\hline $\begin{array}{c}\text { "Tuk-tuk" by Borys } \\
\text { Antonenko-Davydovych }\end{array}$ & & & & & & & + & + & + & + & + & + & + \\
\hline $\begin{array}{c}\text { "Obraza" by Borys } \\
\text { Antonenko-Davydovych }\end{array}$ & & & & & & & + & + & + & + & + & + & \\
\hline $\begin{array}{l}\text { "Shchastia" by Borys } \\
\text { Antonenko-Davydovych }\end{array}$ & & & & & & & + & + & + & + & + & + & \\
\hline $\begin{array}{c}\text { "Shuraburia" } \\
\text { by Borys Antonenko- } \\
\text { Davydovych }\end{array}$ & & & & & & & & & + & & + & + & \\
\hline $\begin{array}{c}\text { "Semen Ivanovych } \\
\text { Palokha" by Borys } \\
\text { Antonenko-Davydovych }\end{array}$ & & & & & & & + & + & + & + & + & + & \\
\hline
\end{tabular}


the German researcher Tatiana Khofman. The masculine topos of Kyiv is represented through the spatial vertical, reveals historical, political, social themes, embodies the success of the characters, their political life. The feminine Kyiv habitus is represented by the spatial horizontal, the reproduction of the hard every day life of the characters who came to conquer the capital, their poverty, famine, the inability of the characters to find harmony between previous experiences of the life in the village and a new existence in the megalopolis.

In the epic works of such writers as Borys Teneta, Maria Galych, Hryhorii Kosynka, Borys AntonenkoDavydovych who belonged to the literary group "Lanka"-MARS, the local habitus of Kyiv is represented as feminine. This is due to the desire of the writers to recreate the life of people in 1920s-1930s, who under difficult circumstances was forced to leave their native village and go to Kyiv, but difficult life is stronger than the desire to conquer the capital and the characters are at the bottom of life, despair and loneliness. Borys Teneta's stories "Harmoniia i svynushnyk", "Misto" and "Holod" represent the antiurban leitmotif and reveal the feminine Kyiv habitus. The characters of Mariia Halych's works "Do birzhi" and "Po dorozi" are in difficult financial circumstances, they feel hopeless. The spatial habitus of Kyiv, created by the writer, has a feminine character. Kyiv in the Borys Antonenko-Davidovich's stories "Tuk-tuk", "Obraza", "Shchastia", "Shuraburia", "Semen Ivanovych Palokha" represents femininity through the reproduction of the difficulties of assimilation to life in the capital, motives of confusion, loneliness. In short story-sketch by Hryhorii Kosynka "Pid bramoiu soboru", which recreates an episode from the life of beggars, presents the feminine Kyiv. Only in "Misto" by Valerian Pidmohylny the binary opposition of the feminine and the masculine in topos of Kyiv is presented. The main character of the novel assimilates into life, passes all the tests of fate, becomes a successful writer, representing the path of ascent from the low (the feminine) to the high (the masculine) urban habitus of Kyiv.

Therefore, the proposed approach of the study of the masculine and the feminine urban habitus makes it possible to understand the connection of the spatial dominants of topos of Kyiv with all components of the writers of the literary group "Lanka"-MARS.

\section{REFERENCES}

[1] M. Liashenko, O. Subina, Learning to be Human: From Philosophical Problem to Humanity
Development Metaphor, Philosophy and Cosmology 24 (2020) 113-121. DOI: https://doi.org/10.29202/phil-cosm/24/11

[2] L. Kavun, Vitaistychna model mista v ukrainskii khudozhnii prozi 1920-kh rokiv, Actual problems of Ukrainian literature and folklore 27 (2019) 719. DOI: https://doi.org/10.31558/23081902.2019.27.1

[3] Ya. Polishchuk, Ukrainska mriia pro vichne misto, Scientific notes of V.I. Vernadsky Taurida National University. Series: Philology. Social communications 31 (70), vol. 1, p. 3 (2020) 215220. DOI: https://doi.org/10.32838/2663$\underline{6069 / 2020.1-3 / 37}$

[4] O. Shevniuk, O. Matviienko, Moral Values and Skills: The Challenges of Space Exploration Practices, Philosophy and Cosmology 23 (2019) 121-129. DOI: https://doi.org/10.29202/phil$\underline{\operatorname{cosm} / 23 / 11}$

[5] V. Dmytrenko, Literaturnyi dyskurs "Lanky"MARSu pershoi tretyny XX stolittia, Publishing House of the State Institution "Luhansk Taras Shevchenko National University”, Luhansk, 2009.

[6] Yu. Kovaliv, Pysmenstvo "rozstrilianoho vidrodzhennia": vid literaturnykh uhrupuvan do Literaturnoi dyskusii, Ukrainian Library, Kyiv, 2004.

[7] S. Lushchii, "Lanka" v literaturnomu dyskursi 20-kh rokiv XX stolittia, in: A wild word, vol. 7, 2012, pp. 50-53.

[8] D. Boklakh, Metafizychnyi modus vidtvorennia toposu mista: interpretatsiia miskoho prostoru Peterburha v poemi "Son" ("U vsiakoho svoia dolia...") T. Shevchenka, Southern archive. Philological sciences 71 (2017) 16-23. DOI: https://doi.org/10.26565/2227-1864-2019-81-03

[9] D. Boklakh, Khudozhni modeli epichnoho toposu Peterburha v povisti "Muzykant" T. Shevchenka in: Literature and Culture of Polissya, vol. 95. Series "Philology Research", vol. 12, 2019, pp. 65 -72. DOI https://doi.org/10.31654/25206966-2019-12f-95-65-72

[10] I. Voloshchuk, The German Topos of Ukraine as a Lost Homeland: Ukrainian Topography in the Poem "Flight Into Kyiv" by Hans-Ulrich Treichel, Kyiv-Mohyla Humanities Journal 5
171-181.
DOI: 
https://doi.org/10.18523/kmhj150399.2018$\underline{5.171-181}$

[11] O. Kin, Re: City of Lions, Kyiv-Mohyla Humanities Journal 5 (2018) 201-204. DOI: https://doi.org/10.18523/kmhj150403.2018$\underline{5.201-204}$

[12] R. Maryniak, Urbanistychnyi i rustykalnyi khudozhnii prostir ta yoho vtilennia $\mathrm{v}$ suchasnii ukrainskii literaturi, Bulletin of V.N. Karazin Kharkiv National University, Series "History of Ukraine. Ukrainian Studies: Historical and Philosophical Sciences" 26 (2018) 51-58. DOI: https://doi.org/10.26565/2225-6505-2018-1-05

[13] N. Mikhno, Misto yak emotsinnyi prostir: teoretyko-sotsiolohichnyi analiz, Facets 3/23 (2020) 82-89. DOI: https://doi.org/10.15421/172028

[14] O. Oliinyk, Misto ta identychnist: u poshukakh samovyznachennia, Art notes 35 (2019) 60-66. DOI: https://doi.org/10.32461/181533

[15] M. Otrishko, Misto yak kulturnyi tekst, Ukrainian culture: past, present, ways of development 31 (2019) 98-103.

DOI: https://doi.org/10.35619/ucpmk.vi31.226

[16] O. Petrenko-Tseunova, Nebesnyi hrad i zemne misto u tvorchosti Hryhoriia Skovorody, Scientific notes of NaUKMA. Literary Studies 2 (2019) 30-35. DOI: https://doi.org/10.18523/2618-0537.2019.2.30$\underline{35}$

[17] D. Chyk, Misto ta povsiakdennist: zhanrovyi riznovyd "fiziolohichnoho narysu" u tvorchosti V. Dalia i Ch. Dikensa, Scientific notes of V.I. Vernadsky Taurida National University. Series: Philology. Social communications 31 (70), vol. 3 , p. 3 (2020) 66-70. DOI: https://doi.org/10.32838/2663-6069/2020.3-3/11

[18] A. Shvets, "Misto u mifichnii dalechyni" (khudozhnia viziia Lvova u prozi Ivana Franka), Ukrainian literary criticism 85 (2020). DOI: http://dx.doi.org/10.30970/uls.2020.85.314 근

[19] T. Khofman, Literary Ethnographies of Ukraine: Prose after 1991, in: https://www.zora.uzh.ch/id/ eprint/132090/1/Diss_russ_Khofman.pdf

[20] V. Pidmohylnyi, Opovidannia. Povist. Romany, Scientific thought, Kyiv, 1991.
[21] B. Teneta, Harmoniia i svynushnyk, Life and revolution 8 (1927) 48-75.

[22] B. Teneta, Misto, Life and revolution 6 (1926) $17-21$.

[23] B. Teneta, Bezrobitnyi, Life and revolution 6-7 (1925) 16-22.

[24] M. Halych, Drukarka: opovidannia, Mass, Kyiv, 1927.

[25] H. Kosynka, Na zolotykh bohiv, Slovo, Kyiv, 1922.

[26] B. Antonenko-Davydovych, Tvory u 2 t, Scientific thought, Kyiv, 1999. 